\title{
Arthropods Associated with Corn Planted in the Marginal Uplands of Inopacan, Leyte
}

\author{
Maria Juliet C. Ceniza and Rosalyn B. Borines \\ Department of Pest Management, Visayas State University, Baybay City, Leyte, \\ 6521-A Philippines
}

\begin{abstract}
A study was conducted to assess and identify the arthropods associated with corn planted in the marginal uplands of Inopacan, Leyte, using pan trap and sweep net methods, done biweekly during the two cropping periods. Two major groups of arthropods were recorded which included the Arachnids and the insect group, consisting of nine (11) orders of insects represented by 59 insects species and 20 spiders. These arthropods belonged to phytophagous groups (chewing and sucking arthropods); natural enemies (predators and parasitoids) and the inocuous groups or considered "others" (scavengers and saprophagous)

The most abundant insect pest species in corn were the Chrysomelidae and Scarabaeidae beetles, while leafhoppers (Homoptera) were moderately abundant in the crop. The predators were mostly ants (Hymenoptera), the spiders (Arachnids), and coccinellid beetles. The parasitoids included the braconid, ichneumonid, and chalcid wasps. The most abundant non-pest and inocuous species are the Dipterans which are potential hosts or prey of the biotic agents in the corn ecosystem.

The abundance of pest species in corn is not yet alarming, which indicates that the pests are not attracted to the crops which were marginal in growth. The natural enemies were also occurring in moderate numbers adequate to suppress abundance of pest species. However, from the results, the corn planted in the marginal upland with chicken dung was observed to have the higher number of insect associations than the other treatments.
\end{abstract}

Keywords: Arthropods, Marginal Uplands

Correspondence : M.J. Ceniza Address: Department of Pest Management, Visayas State University, Baybay City, Leyte,6521-A Philippines Email:mjjceniza@61@yahoo.com

DOI: 10.32945/atr36s10.2014 


\section{INTRODUCTION}

Uplands in the Philippines constitute $60 \%$ of the country's total land area (DENR-ERDB, 2010), where agriculture and forestry are practiced on rolling to steep land, with slopes ranging upward from 18\%. The natural resources of the uplands provide a livelihood for people, through land uses in agriculture, among others (Sajise, 2005). They are continuously pressured by increasing migration of lowland population to these areas converting it to become marginal, because of activities such as uncontrolled exploitation of forest, shifting cultivation, conversion to agricultural lands, overgrazing and improper agricultural practices. Thus, the upland is no longer capable of sustaining productivity to support the needs of human society (Sajise, 1986). At present, it is characterized by barren denuded hills and mountains mainly vegetated with cogon and brush with only few trees remaining in the area.

Innovative and sustainable farming technologies and alternative livelihoods that are based on sufficient understanding of the biophysical and socio-economic factors affecting agricultural production in every marginal upland are needed to address these problematic situations. Agricultural farming design is crucial to bring back biodiversity as well as productivity of the land. The program on enhancing farm productivity as well as environmental quality in these highly vulnerable areas is very significant. One of the important components in this program is addressing pest problems which are very crucial in improving farm produce without sacrificing effects in the environment and health of the farmers. Environment friendly pest management practices are crucial for sustainable food production especially in fragile and highly degraded marginal areas.

Arthropods constitute the most species of any taxa in the uplands and are critical in upland food chains. Typically, they contribute over half the invertebrate species in any habitat or ecosystem occupying several trophic levels, vital functions and varied habits within ecosystems. The bulk of them are herbivorous, but certain species have utility value as natural enemies of herbivore pests in the uplands and as important decomposers to enhance organic accumulation in poor marginal soils. However, scanty information/literatures are available on the arthropod association of any crop planted in the uplands and their status. The first step in managing insect pests is to identify the insect and determine the numbers present. This information can then be used to determine whether control is 
Arthropods Associated with Corn Planted in the Marginal Uplands

required and to decide on the most suitable management method. Results of studies like these would provide options for better or effective strategies for crop management in the marginal uplands. To address this gap, this study aimed to identify arthropod associations with crops, particularly corn which are planted in the marginal uplands of Inopacan, Leyte.

The objectives of this study are:

1. assess and identify the major arthropods associated with corn planted in marginal uplands of Inopacan, Leyte with organic soil amendments;

2. monitor the abundance and dynamics of the major arthropods of corn; and

3. determine the trophic functions of the arthropod association of corn plants.

\section{METHODOLOGY}

\section{Sampling site and treatments}

The study was conducted in the marginal uplands of Brgy. Linao,Sitio Batuan of Inopacan Leyte, approximately 4 kilometers away from the National highway. An area of $527 \mathrm{~m}^{2}$ planted to corn was established. Sampling was made on the corn plants treated with organic amendments. The data were taken from corn plants with the treatments, as follows: $\mathrm{T}_{0}=$ $(0-0-0) ; \mathrm{T}_{1}=15$ tha $^{-1}$ chicken dung and $\mathrm{T}_{2}=15$ tha $^{-1}$ Vermicast.

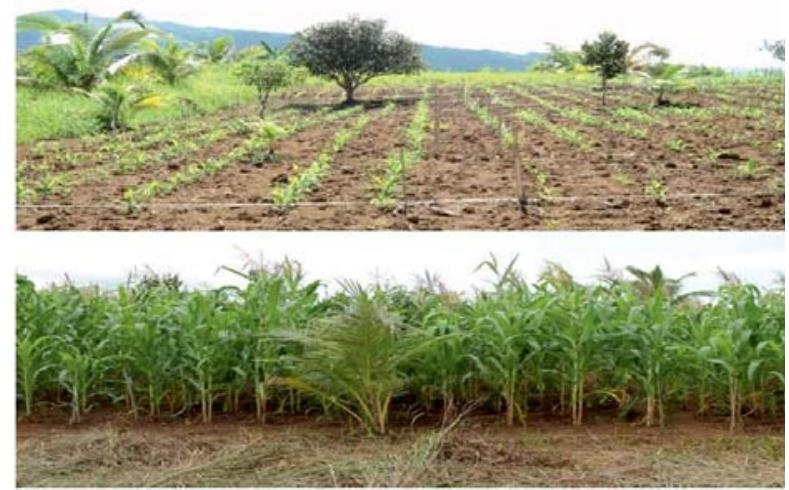

Figure. 1. Marginal uplands in Sitio Batuan, Inopacan, Leyte planted to corn plants used as study site 
Each treatment plot measured $4 \mathrm{~m} \times 4.5 \mathrm{~m}\left(18 \mathrm{~m}^{2}\right)$ with 6 rows per plot. The treatments used were replicated three times. Each treatment has six rows which comprised 10 plants. Arthropod sampling and monitoring was done two weeks after planting until harvest

\section{Sampling Methods and Collections of Arthropods}

Biweekly sweep net and pan trap sampling was done to collect the arthropods associated with corn, commencing from the $2^{\text {nd }}$ week after planting (March 2013) until harvest (July 2013).

Sweeping method was done using hand sweep net measuring $50 \mathrm{~cm}$ rim diameter. A handle of about 1 meter long was provided to swing the net over the vegetation. Sweeping was done over the vegetation while walking in straight lines, making sure all plants in the plot were swept. Three plots per replication were sampled. The arthropods collected were killed first in jars with chloroform and transferred to a bottle with 70\%ethyl alcohol for sorting and examination.

Yellow pan traps $(240 \mathrm{~mm}$ by $150 \mathrm{~mm}$ ) were set-up per treatment plots. These were set at random in the middle of the treatment plot for 3 days, left twice a month in each sampling site. These traps were positioned at a ground level, but the rim of the trap was only around $5 \mathrm{~cm}$ from the ground surface (Hammond 1990). Each pan trap was filled with salt, soap and water mixture in order to last up to several days (Bagarinao 1992). The catch was retrieved after 3 days and transferred to a container with 70\% ethyl alcohol in the laboratory for sorting and identification.

Sorting, preparation of samples and identification/classification of arthropods and data analysis

\section{Data Analysis}

Specimens, including immatures and adults collected from corn plants were brought to the laboratory/museum and sorted by taxonomic category then counted. Identification and classification was done to segregate pests and natural enemies using available references. Specimens with uncertain identities were sorted according to obvious morphological differences and preserved for future identification. A reference collection was established to facilitate subsequent identification of arthropods. 
Arthropods Associated with Corn Planted in the Marginal Uplands

All data gathered were pooled and analyzed using appropriate computations for abundance and population counts. Graphical representation of the abundance of major arthropods was done.

\section{RESULTS AND DISCUSSION}

Arthropod composition and structure associated with corn plants

An average of 269 arthropods associated with corn plants, representing 2 classes namely: Class Insecta and Class Arachnida were recorded using sweepnet method while 124 arthropods specimen were collected using pan trap method (Table 1). Class Insecta comprised the bigger bulk in both sampling methods used, represented by 11 orders. These were categorized as pest and non-pest species (Figure 2).

Table 1. Mean number of arthropods associated with Corn (Zea mays) planted in marginal upland in Inopacan Leyte for two croppings using sweepnet and pantrap methods.

\begin{tabular}{llrr}
\hline \multicolumn{1}{c}{ Class/Order } & & Sweepnet & Pantrap \\
\hline Class Insecta & & & \\
& Blattodea & 2.0 & 1.0 \\
& Coleoptera & 53.5 & 10.0 \\
& Hemiptera & 5.5 & 0.0 \\
& Homoptera & 31.0 & 8.5 \\
& Hymenoptera & 97.5 & 41.0 \\
& Diptera & 41.5 & 45.0 \\
& Odonata & 2.0 & 0.0 \\
& Lepidoptera & 9.0 & 6.0 \\
& Orthoptera & 14.0 & 4.0 \\
& Neuroptera & 0.5 & 0.0 \\
& Isoptera & 0.0 & 0.5 \\
Class & & & \\
Arachnida & Aranaeida & 13.0 & 7.5 \\
\hline Grand Total & & 269.5 & 123.5 \\
\hline
\end{tabular}

These orders included some pests which were categorized into phytophagous, i.e chewing and sucking arthropods while the non-pest were classified as predators and parasitoids (Table 2). On the other hand, the inocuous groups or considered as "others" are the scavengers or saprophagous (Table 2). Figure $2 \mathrm{a}$ and $2 \mathrm{~b}$ show the number of pest and non-pest associated with corn amended with chicken dung, vermicasts and an untreated control. 
Results showed that regardless of treatments, the arthropods associated with corn were predominantly non-pest species collected by both sampling methods. However, the sweep net method yielded more of arthropods than the pan trap samples, since this is active sampling. Pan traps rely on the chances of arthropods attracted and to fall in the trap. Pest species sampled are not very abundant and alarming considering that almost negligible number was recorded in the control. On the other hand, potential natural enemies are quite high in number, almost double the abundance of pest species.
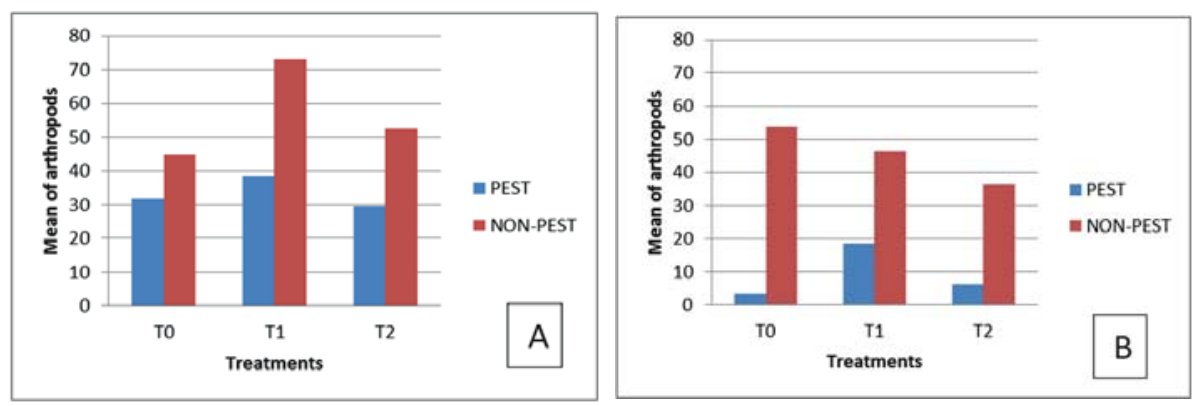

Figure 2. Number of pest and non-pest associated with corn (Zea mays) planted in marginal upland in Inopacan, Leyte using (A) sweep net method and (B) pantrap method. Treatments: $\mathrm{T}_{0}=(0-0-0), \mathrm{T}_{1}=15$ tha $^{-1}$ chicken dung, and $\mathrm{T}_{5}=15$ tha $^{-1}$ Vermicast

Figures $3 \mathrm{a} \& 3 \mathrm{~b}$ and $4 \mathrm{a} \& 4 \mathrm{~b}$ showed the total number of pests by orders using the sweepnet and pan trap methods. Among the pest species, the beetles (Order Coleoptera) were the most abundant (Fig. 3A) followed mainly by Homoptera in descending orders, sampled in the sweep net method. For the pan trap, a number of Orthopterans were additionally sampled. From the results of the arthropod abundance, the corn plants fertilized with chicken dung (T1) seemed to have consistently higher numbers of pest species than those with no amendments and with vermicast. It is highly possible that addition of chicken dung have influenced the number of arthropods that get attracted to the corn plants probably because of the good stature of the crop under this treatment. This result contradicts to the study made by Chau and Heong (2005) which found out reduced number of pest species in rice with organic fertilization. However, organic fertilization improves the growth and performance of crop. 
Arthropods Associated with Corn Planted in the Marginal Uplands

Non-pest species included Hymenoptera, Diptera, and some Coleopteran predators, with the Hymenoptera contributing to the bulk, comprised mainly of ants (Fig. 3B and 4B). Arachnids, comprising of spiders were also recorded in moderate abundance.
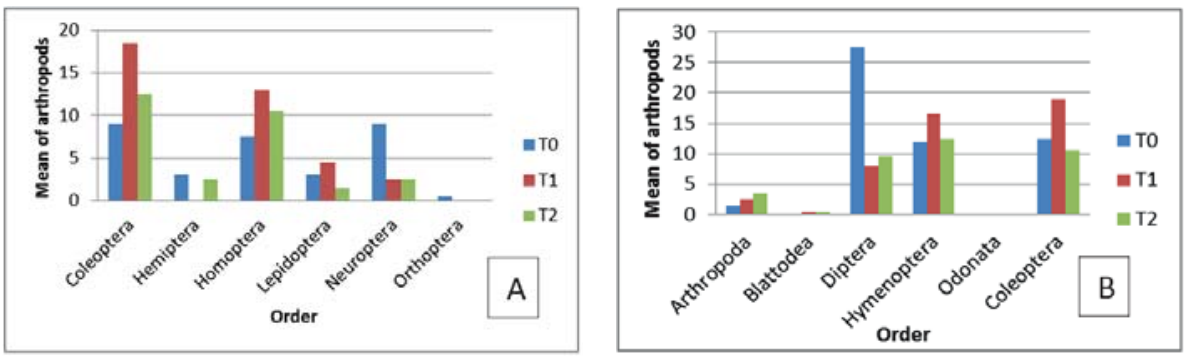

Figure 3. Mean number of (A) Pest and (B) non-pest by order associated with Corn (Zea mays) planted in marginal upland in Inopacan, Leyte collected using sweep net method. Treatments: $\mathrm{T}_{0}=$ control, $\mathrm{T}_{1}=$ chicken dung, $\mathrm{T}_{2}=$ vermicast
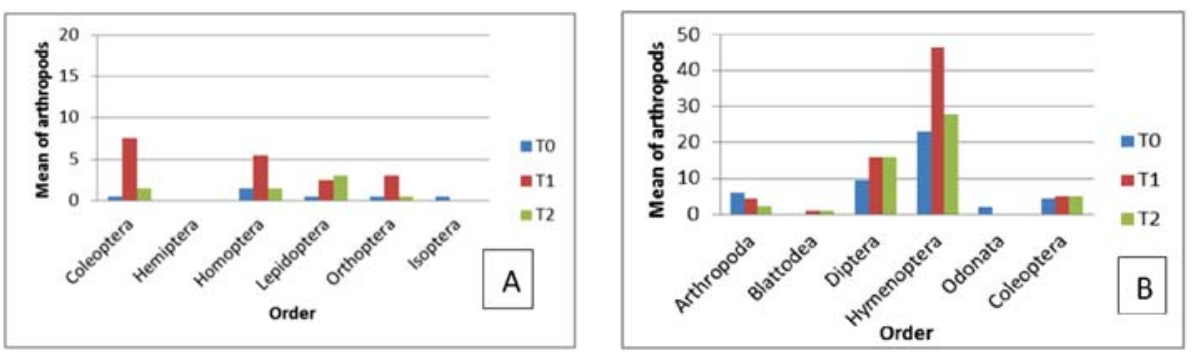

Figure 4. Mean number of (A) pest and (B) non-pest by order associated with Corn (Zea mays) planted in marginal upland in Inopacan, Leyte using pantrap method. Treatments: $\mathrm{T}_{0}=$ control, $\mathrm{T}_{1}=$ chicken dung, $\mathrm{T}_{2}=$ vermicast

In terms of specific families recorded, Figures 5a, 5b, and 6 showed trend of abundance of these major families collected in both methods during the duration of the sampling periods. The graphs showed that major families of Coleoptera were the Chrysomelidae followed by Scarabaeidae and Curculionidae in descending orders (Figures 5A and 5B). This is true for both the sweep net and the pan trap samples. The results implied that the increasing abundance of the arthropods coincided with the vegetative stage of the corn plant, which is logically the most attractive stage of plants to herbivores. The scarab beetles and leaf beetles are common groups of the herbivores attacking corn, which are feeding mainly on the leaves. 
Among the Homopterans, the leafhoppers (Cicadellidae) appeared to be the commonly occurring group throughout the sampling period in the pan trap method (Fig. 6). Leafhoppers are obviously suckers of the saps of the leaves so they were attracted to the pan trap. However, it is clear that their numbers or abundance is not very alarming considering the number of individuals sampled. Moreover, it should be noted that these arthropods are potential pests of corn in the uplands, thus future farming design that integrates corn in the marginal uplands has to take this into consideration.
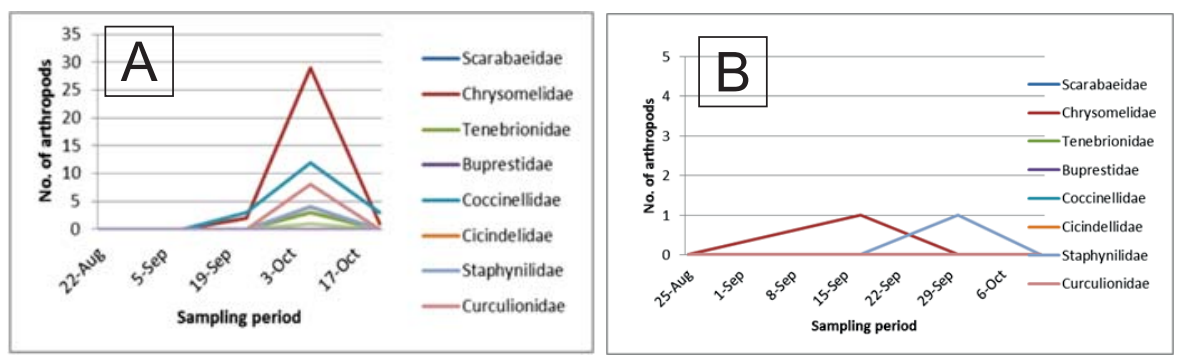

Figure 5. Number of individuals by families of Coleoptera associated with Corn (Zea mays) planted in marginal upland in Inopacan, Leyte using (A) sweep net method and (B) pan trap method.

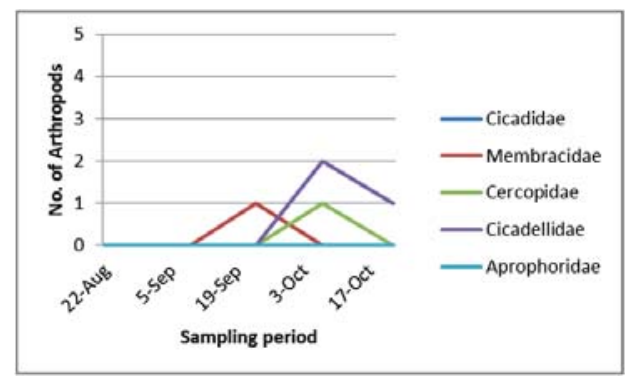

Figure 6. Number of individuals by families of Homoptera associated with Corn (Zea mays) planted in marginal upland in Inopacan, Leyte using pantrap method.

Figures 7 shows the commonly occurring families of non-pest arthropod species associated with corn, largely dominated by Hymenoptera, specifically the ants. Ants are general predators and with the presence of potential prey species during the vegetative stage of the corn plants, their number is expected to be greatly high. 
Arthropods Associated with Corn Planted in the Marginal Uplands

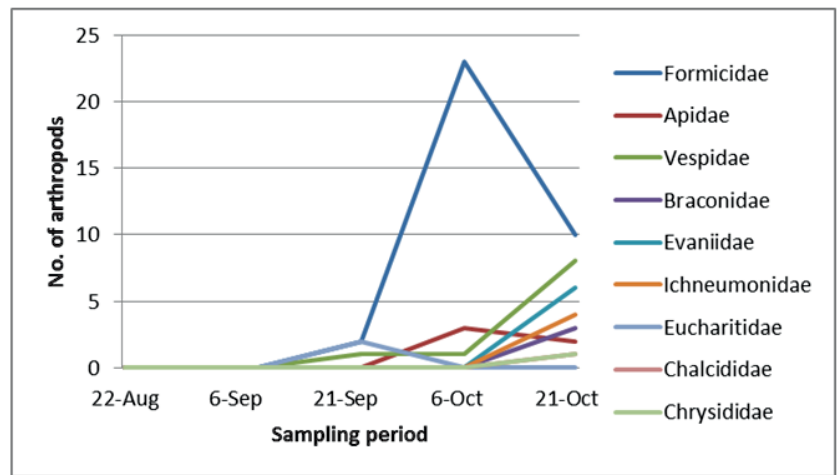

Figure 7. Number of individuals by families of Hymenoptera associated with Corn (Zea mays) planted in marginal upland in Inopacan, Leyte collected using sweep net method.

Ants are known to be a major component in arthropod fauna. They, however, contributed only in terms of the number of individuals (Stork 1991, Hammond 1990). In terms of species, breakdown of composition for each family is presented in Table 2. A total of 59 species of insects were recorded to be associated with the corn in addition to the 20 species of Araneae or the spiders that were also observed. As discussed, these species assumed varied roles in the corn ecosystems from being phytophagous, predatory, parasitoids or as innocuous species.

\section{CONCLUSION}

Corn planted in the marginal uplands do hosts a diverse group of arthropods which are potential pests and biological control agents. Their numbers, however, were seemingly not alarming considering probably the performance corn under marginal upland conditions. The most abundant insect pest species in corn were the beetles (ColeopteransChrysomelidae) and leafhoppers (Homoptera-Cicadellidae). Ants (Hymenoptera-Formicidae) were the most abundant non-pest groups in both crops and in both sampling methods, followed by Arachnids (spiders). Arthropod abundance recorded were observed to vary with stage of the plant growth. Corn plants fertilized with chicken dung seemed to host more number of pest and non-pest arthropods than the other organic soil amendments. 
Table. 2. Number and trophic functions of identified species in each family of arthropod orders observed to be associated with corn planted in the marginal uplands of Inopacan, Leyte.

\begin{tabular}{|c|c|c|c|c|c|}
\hline Class & Order & Family & $\begin{array}{l}\text { No. of } \\
\text { Species }\end{array}$ & Species name & Trophic functions \\
\hline \multirow[t]{31}{*}{ Class Insecta } & \multirow[t]{8}{*}{$\begin{array}{l}\text { Blattodea } \\
\text { Coleoptera }\end{array}$} & $\begin{array}{l}\text { Blattellidae } \\
\text { Scarabaeidae }\end{array}$ & $\begin{array}{l}2 \\
1\end{array}$ & $\begin{array}{l}\text { Blattella germanica } \\
\text { Blatta orientalis }\end{array}$ & \multirow{4}{*}{$\begin{array}{l}\text { Scavengers } \\
\text { saprophagous } \\
\text { Pest, chewing } \\
\text { Pest; chewing } \\
\text { Pest; chewing }\end{array}$} \\
\hline & & Chrysomelidae & 2 & Monolepta sp. & \\
\hline & & Tenebrionidae & 1 & & \\
\hline & & Buprestidae & 1 & & \\
\hline & & Coccinellidae & 2 & Micraspis sp. & predators \\
\hline & & Cicindellidae & 2 & & predators \\
\hline & & Staphylinidae & 1 & & predators \\
\hline & & Curculionidae & 1 & Pachyrrhynchus sp. & Pest; chewing \\
\hline & \multirow[t]{4}{*}{ Hemiptera } & Coreidae & 1 & & Pest; sucking \\
\hline & & Alydidae & 1 & Leptocoriza oratorius & Pest, sucking \\
\hline & & Plataspidae & 1 & & Pest, sucking \\
\hline & & Pentatomidae & 1 & & Pest, sucking \\
\hline & \multirow[t]{4}{*}{ Homoptera } & Cicadidae & 1 & & Pest, sucking \\
\hline & & Membracidae & 2 & & Pest, sucking \\
\hline & & Cercopidae & 1 & & Pest, sucking \\
\hline & & Cicadellidae & 6 & Nephotettix spp. & \multirow{4}{*}{$\begin{array}{l}\text { Pest, sucking } \\
\text { predators } \\
\text { pollinators } \\
\text { pollinators }\end{array}$} \\
\hline & \multirow[t]{11}{*}{ Hymenoptera } & Formicidae & 2 & & \\
\hline & & \multirow[t]{2}{*}{ Apidae } & \multirow[t]{2}{*}{2} & Apis sp. & \\
\hline & & & & Trigona sp. & \\
\hline & & Vespidae & 3 & & \\
\hline & & Braconidae & 1 & & parasitoids \\
\hline & & Evaniidae & 2 & & parasitoids \\
\hline & & Ichneumonidae & 2 & & parasitoids \\
\hline & & Eucharitidae & 1 & & parasitoids \\
\hline & & Chalcididae & 1 & & parasitoids \\
\hline & & Chrysididae & 1 & & parasitoids \\
\hline & & Unidentified & 1 & & \\
\hline & \multirow[t]{4}{*}{ Diptera } & Muscidae & 1 & Musca domestica & \multirow[t]{2}{*}{ saprophagous } \\
\hline & & Calliphoridae & 1 & & \\
\hline & & Drosophilidae & 1 & & \multirow[t]{2}{*}{ saprophagous } \\
\hline & & Micropezidae & 1 & & \\
\hline
\end{tabular}


Arthropods Associated with Corn Planted in the Marginal Uplands

Table 2 continuation.

\begin{tabular}{|c|c|c|c|c|c|}
\hline Class & Order & Family & $\begin{array}{c}\text { No. of } \\
\text { Species }\end{array}$ & Species name & Trophic functions \\
\hline & Diptera & Sarcophagidae & 1 & & parasitoids \\
\hline & & Dolicophoridae & 1 & & \\
\hline & Odonata & Libellulidae & 1 & & predators \\
\hline & Lepidoptera & Arctiidae & 1 & & pest \\
\hline & & Noctuidae & 2 & & pest \\
\hline & & Lycaenidae & 2 & Hippotion sp. & pest \\
\hline & & Pyralidae & 1 & & pest \\
\hline & & Yponomeutidae & 1 & & \\
\hline & Orthroptera & Tettigoniidae & 1 & & Pest, chewing \\
\hline & & Gryllidae & 1 & & Pest,chewing \\
\hline & & Acrididae & 1 & Gesomula mundata & $\begin{array}{l}\text { Pest, chewing } \\
\text { predators }\end{array}$ \\
\hline $\begin{array}{l}\text { Class } \\
\text { Arachnida }\end{array}$ & Aranaeida & $\begin{array}{l}\text { Assorted } \\
\text { families }\end{array}$ & 20 & & \\
\hline
\end{tabular}

\section{REFERENCES}

BAGARINAO, N. 1992. Diversity and abundance of arthropods on Gliricidia sepium hedgerows in an upland farm. B.Sc. Thesis, Visayas State College of Agriculture, Department of Plant Protection. (unpublished).

BELFIELD and BROWN, C. 2009. A guide to upland cropping in Cambodia: maize. ACIAR Monograph No. 140, 43 pp. ISBN 9781921531590 (online).

CHAU, L. M and K.L. HEONG. 2005. Effects of organic fertilizers on insect pest and diseases of rice. Omonrice. 13:26-33.

DENR-ERDB. 2010. Rehabilitation and Ecological Restoration R \& D for Marginal and Degraded Landscapes and Seascapes. A Research Compendium for Marginal Uplands. $81 \mathrm{pp}$.

HAMMOND, P. M. 1990. Insects abundance and diversity in Dumoga-Bone National Park, N, Sulawesi, with special reference to the beetle fauna of lowland rain forest in the Toraut region. In: W. J. Knight and J.D. Holloway (eds). Insects and the rainforests of Southeast Asia (Wallacea). The Royal Entomological Society of London, pp 197- 254. 
SAJISE, P. 1986. The Changing Upland Landscape. In: Man, Agriculture, and the Tropical Forest, edited by S. Fujisaka, P. Sajise, and R. del Castillo. Winrock International, Bankok. 13 -41.

SAJISE, P. 2005. The sustainable livelihood framework in understanding good practices on on-farm conservation of tropical fruits. Paper presented at the UNEP-GEF and IPGRI meeting on good practices for Conservation and Sustainable Use of Tropical Fruits and its Wild Relatives.4-5 April 2005, Bangkok, Thailand.

STORK, N. 1991. The composition of the arthropod fauna of Bornean lowland rainforest trees. Journal ofTropical Ecology, 7, 161-180. 